\title{
Analisis Kualitas Total Tim Himpunan Mahasiswa Pendidikan Akuntansi
}

\author{
Purweni Widhianningrum
}

Dosen Program Studi Pendidikan Akuntansi IKIP PGRI Madiun

weni.widhi@gmail.com

\begin{abstract}
Abstrak
Penelitian ini bertujuan untuk menguji pengaruh Kualitas Total Individu (yang terdiri dari kepemimpinan pribadi, perencanaan, dan perbaikan terus-menerus) terhadap Kualitas Total Tim Himpunan mahasiswa Pendidikan Akuntansi (Himadiksi).

Populasi penelitian ini adalah seluruh mahasiswa Program Studi Pendidikan Akuntansi yang sekaligus menjadi anggota Himadiksi IKIP PGRI Madiun angkatan tahun 2010, 2011, dan 2012 dengan jumlah 298 mahasiswa. Teknik pengambilan sampel dilakukan dengan metode purposive sampling sehingga total sampel yang digunakan sejumlah 46 responden. Teknik pengumpulan data dilakukan dengan wawancara dan kuesioner. Metode analisis data yang digunakan adalah regresi berganda.

Hasil penelitian menunjukkan bahwa secara secara parsial, variabel kepemimpinan pribadi dan perencanaan tidak berpengaruh terhadap kualitas total tim Himadiksi, hanya variabel perbaikan terus-menerus yang menunjukkan pengaruh positif dan signifikan terhadap kualitas total tim Himadiksi. Hal ini membuktikan bahwa setiap anggota tim selalu terbuka pada kritikan dan memandang setiap masalah yang timbul merupakan suatu kesempatan untuk melakukan perbaikan terus-menerus agar membawa perubahan bagi diri sendiri dan Kualitas Total Tim Himadiksi.

Kata Kunci : kualitas total tim, kualitas total individu, kepemimpian pribadi, perencanaan, dan perbaikan terus-menerus.
\end{abstract}

\begin{abstract}
This study aimed to examine the influence of Total Quality Individuals (which consists of personal leadership, planning, and continuous improvement) on Total Quality Team of Himpunan Mahasiswa Pendidikan Akuntansi (Himadiksi).

The population in this study were all students of Accounting Departement as well as a member of Himadiksi IKIP PGRI Madiun class of 2010, 2011, and 2012 with the number of 298 students. The sample obtained based on purposive sampling method, so that the total number of samples used 46 respondents. Data was collected by interviews and questionnaires. The method of data analysis used is multiple regression.

The results showed that partially, personal leadership and planning variables did not influence total quality Himadiksi team, only variable continuous improvement that showed positive and significant impact on the total quality team Himadiksi. It is proved that every member of the team is always open to criticism and view each problem that arises is an opportunity to make continuous improvement in order to bring a change for themselves and total quality team Himadiksi.
\end{abstract}

Keywords: total quality individuals, total quality team, personal leadership, planning, and continuous improvement. 


\section{Latar Belakang}

ASEAN Economic Comunity merupakan gerbang terbuka bagi dunia bisnis untuk saling berkompetisi dengan pelaku bisnis lain dari berbagai Negara di ASEAN, tak terkecuali dunia pendidikan. Tantangan bagi dunia pendidikan di Indonesia saat ini adalah menghasilkan lulusan perguruan tinggi yang sesuai dengan kebutuhan para pengguna jasa serta mampu bersaing secara global.

Semakin tingginya tingkat pengangguran lulusan perguruan tinggi di Indonesia serta semakin banyaknya tenaga kerja asing dari perguruan tinggi luar negeri memasuki pasar tenaga kerja, menunjukkan bahwa lulusan perguruan tinggi di Indonesia tidak mampu beradaptasi dengan kebutuhan dunia industri modern. Padahal kebutuhan dunia bisnis dan industri terhadap lulusan perguruan tinggi di Indonesia lebih menekankan pada kemampuan mereka sebagai problem solver, dimana mahasiswa dituntut untuk: (1) kreatif, (2) berkarakter pemimpin, (3) analitikal, (4) tersruktur, (5) sistematik, (6) intuitif, (7) kritis, (8) informatif, (9) synthesizer, dan (10) berorientasi team (Gasperz dan Fontana, 2011). Kesenjangan ini dikarenakan, sistem pendidikan yang dilaksanakan di Indonesia saat ini kurang berorientasi kepada penumbuhan kreativitas dan produktivitas (Barizi dan Idris, 2009:25).

UNESCO menekankan pentingnya empat pilar yang harus dilakukan dalam proses pendidikan, yaitu: (1) Belajar untuk mengetahui (learning to know), (2) Belajar untuk berbuat (learning to do), (3) Belajar untuk mandiri (learning to be), dan (4) belajar untuk hidup bersama (learning to live together). Keempat pilar yang dijelaskan di atas, dapat diperoleh dalam proses pendidikan akademik maupun non akademik (Komariah dan Triatna, 2008:67).

Hasil studi Harvard University, Amerika Serikat mengungkapkan bahwa kesuksesan seseorang dalam meniti karir dan kehidupan hanya ditentukan sekitar $20 \%$ oleh pengetahuan dan keterampilan teknis (kemampuan menghitung dan menganalisa) atau hard skill, dan sisanya $80 \%$ oleh keterampilan mengelola diri dan orang lain atau soft skill (Utomo, 2010). Soft skills merupakan seperangkat kemampuan yang mempengaruhi bagaimana kita berinteraksi dengan orang lain, diantaranya: komunikasi efektif, berpikir kreatif dan kritis, membangun tim, serta kemampuan lainnya yang terkait kapasitas kepribadian individu (Widhiarso, 2009).

Kemampuan dalam mengelola serta mengembangkan perguruan tinggi saat ini dirasa perlu menggunakan prinsip-prinsip manajemen modern yang berorientasi pada mutu untuk memperbaiki, menyempurnakan, dan menyiapkan diri ke gerbang persaingan global (Narimawati, 2014). Cara terbaik agar dapat bersaing dan unggul dalam persaingan global adalah dengan menghasilkan kualitas yang terbaik. Untuk menghasilkan kualitas terbaik 
diperlukan upaya perbaikan berkesinambungan terhadap kemampuan manusia, proses, dan lingkungan (Fitriyah dan Ningsih, 2013).

Proses perbaikan kualitas lulusan perguruan tinggi senantiasa dilakukan oleh Program Studi Pendidikan Akuntansi IKIP PGRI Madiun melalui pembentukan organisasi Himpunan Mahasiswa Pendidikan Akuntansi (Himadiksi), sebagai wujud komitmen Program Studi Pendidikan Akuntansi untuk meningkatkan kompetensi Akademis dan Non Akademis Mahasiswa sebelum memasuki dunia kerja. Dengan dibentuknya Himadiksi, diharapkan mahasiswa pendidikan akuntansi tidak hanya mampu meningkatkan kompetensi akademik saja, namun juga mampu mengembangkan potensi diri, meningkatkan kerjasama dan solidaritas, menjadi pribadi yang mandiri, tanggungjawab dan profesional.

Teamwork merupakan kumpulan tenaga kerja yang berusaha untuk mencapai kualitas pekerjaan yang dilakukan secara bersama- sama (Semuel dan Zulkarnain, 2011). Faktor yang mendasari perlunya dibentuk tim dalam sebuah organisasi adalah agar anggota tim dapat saling mengenal dan saling percaya sehingga dapat saling membantu, serta membina komunikasi yang baik antar anggota tim (Tjiptono dan Diana, 2003:165). Kerja organisasi tidak akan terlaksana jika para anggota organisasi tidak bekerja sama secara selaras, karena itu sangat dibutuhkan kerjasama dalam organisasi (Anthony et.al, 1984 dalam Poernomo, 2006).

Kerja tim dalam sebuah organisasi merupakan komponen penting dalam implementasi Total Quality Management, mengingat kerja tim akan meningkatkan kepercayaan diri, komunikasi, dan mengembangkan kemandirian (Oakland, 1989 dalam Sallis, 2011). Konsepkonsep yang digunakan dalam kerja tim untuk meningkatkan proses dan kegiatan adalah: keterlibatan setiap anggota tim, kepemimpinan mandiri, dan lingkaran mutu (Milosan, 2011).

Kunci keberhasilan kerjasama tim ditentukan oleh: (1) Pertumbuhan individu, dimana setiap individu dalam kelompok kerja mampu mencapai tujuan individu dan tujuan kelompok sehingga dapat memberikan pertanggungjawaban terhadap pencapaian kinerja kelompok secara keseluruhan; (2) Pekerjaan kelompok, membutuhkan komitmen para anggota ketika bekerja dalam sebuah kelompok kerja; dan (3) Kinerja kelompok secara keseluruhan, dapat dilihat dari peran individu dalam mendukung upaya pencapaian kinerja kelompok (Stoner, Freeman, dan Gilbert, 1995 dalam Sule dan Saefullah, 2010:290)

Kualitas total merupakan kunci persaingan dalam pasar global yang meliputi kualitas produk, kualitas biaya atau harga, kualitas keamanan, kualitas pelayanan, kualitas penyerahan tepat waktu dan kualitas semangat guna memberikan kepuasan terus-menerus kepada pelanggan. Kualitas ini dimulai pertama kali dari dalam diri individual, dimana kunci 
keberhasilan setiap aktivitas di dunia sangat tergantung pada kualitas individu yang nantinya akan membentuk kualitas manajemen dalam suatu organisasi yang berkualitas (Gasperz dan Fontana, 2011). Seseorang dengan pribadi sempurna dan memiliki empat paradigma yang melekat dalam dirinya, yaitu: kesehatan fisik, intelektual, emosional dan spiritual disebut sebagai Total Quality Person (Chapaign, 2013).

Hasil studi empiris yang dilakukan oleh Tobing dan Fitriati (2009) serta Fitriyah dan Ningsih (2013), menunjukkan bahwa semakin tinggi kualitas sumber daya manusia yang dimiliki oleh sebuah organisasi dapat mendorong terciptanya kerjasama tim yang baik dan pada akhirnya mampu memaksimalkan kinerja organisasi secara keseluruhan. Tobing dan Fitriati (2009) mengungkapkan bahwa setiap individu yang memiliki keyakinan akan tercapainya sebuah cita-cita, menerapkan inovasi kreatif, dan terus melakukan perbaikan jika mengalami kegagalan dalam bekerja merupakan karakteristik seseorang yang berkompetensi tinggi.

Berdasarkan latar belakang di atas, penelitian ini bertujuan untuk menguji pengaruh signifikan dari Kualitas Total Individu (yang terdiri dari kepemimpinan pribadi, perencanaan, dan perbaikan terus-menerus) terhadap Kualitas Total Tim Himadiksi.

\section{Metode Penelitian}

Populasi penelitian ini adalah seluruh mahasiswa Program Studi Pendidikan Akuntansi yang sekaligus menjadi anggota Himadiksi IKIP PGRI Madiun angkatan tahun 2010, 2011, dan 2012 dengan jumlah 298 mahasiswa. Teknik pengambilan sampel dilakukan dengan purposive sampling, dimana responden yang digunakan dalam penelitian ini merupakan anggota Himadiksi angkatan tahun 2010, 2011, dan 2012 serta berperan aktif sebagai pengurus Himadiksi periode tahun 2012, 2013, dan 2014. Total sampel yang digunakan dalam penelitian ini adalah 46 responden.

Data dikumpulkan melalui wawancara dan kuisioner. Penelitian ini menggunakan skala Likert, yang terdiri dari lima pilihan jawaban atas pernyataan yang diajukan sehingga menjadi selalu diberi skor 5, sering diberi skor 4, kadang-kadang diberi skor 3, jarang diberi skor 2 dan tidak pernah diberi skor 1 .

\section{Definisi Operational Variabel}

Variabel dependen dalam penelitian ini adalah Kualitas Total Tim (Y). Indikator Kualitas Total Tim dalam penelitian ini adalah: (1) Tanggung jawab, (2) Kekompakan, (3) Komunikasi, dan (4) Kesamaan Tujuan 
Variabel independen dalam penelitian ini adalah Kualitas Total Individu (X) yang terdiri dari:

X1 Kepemimpinan Pribadi

X1.1 Komunikasi yang baik

X1.2 Motivasi diri

X1.3 Gesit dan inovatif

X2 Perencanaan

X2.1 Menetapkan visi dan tujuan

X2.2 Penjadwalan kerja

X2.3 Merancang prosedur

X3 Perbaikan Terus-menerus

X3.1 Memiliki keinginan terus belajar

X3.2 Menerima perubahan

X3.3 Mengukur tingkat keberhasilan

X3.4 Melakukan perbaikan cara kerja

Kerangka konsep dalam penelitian ini menjelaskan bahwa Kualitas Total Tim Himadiksi dipengaruhi oleh variabel kepemimpinan pribadi, perencanaan, dan perbaikan terus-menerus seperti yang disajikan dalam gambar berikut ini:

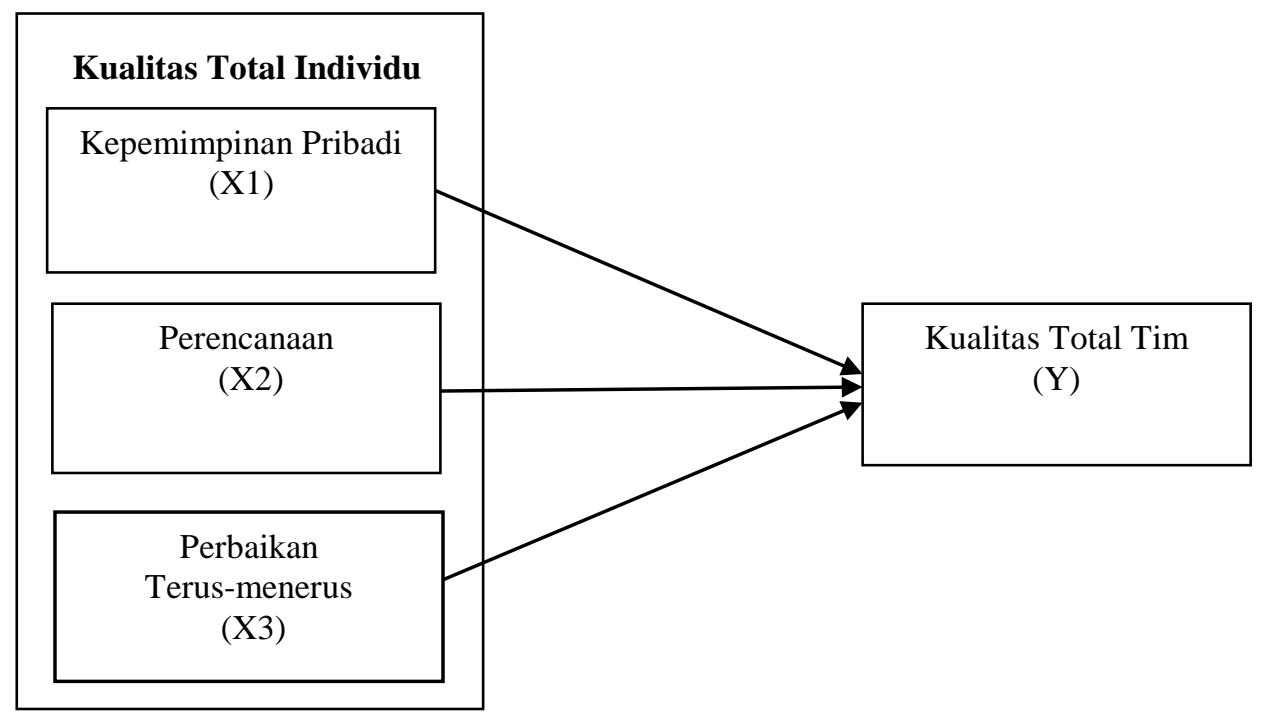




\section{Gambar 1 : Kerangka Konsep}

Berdasarkan kerangka konsep penelitian, maka diajukan hipotesis penelitian sebagai berikut:

H1 : Kepemimpinan pribadi berpengaruh signifikan terhadap Kualitas Total Tim Himadiksi

H2 : Perencanaan berpengaruh signifikan terhadap Kualitas Total Tim Himadiksi

H3 : Perbaikan terus-menerus berpengaruh signifikan terhadap Kualitas Total Tim Himadiksi

Model empiris yang digunakan dalam penelitian ini adalah model regresi berganda, dengan alat analisis SPSS versi 20.0. Bentuk dari model regresi berganda dalam penelitian ini adalah sebagai berikut:

$$
Y=\beta_{0}+\beta_{1} X_{1}+\beta_{2} X_{2}+\beta_{3} X_{3}+\varepsilon
$$

Keterangan:

$$
\begin{array}{ll}
\mathrm{Y} & =\text { Kualitas Total Tim } \\
\beta_{0} & =\text { Konstanta } \\
\beta_{1 \ldots \ldots . . .} \beta_{4} & =\text { Koefisien Regresi } \\
\mathrm{X}_{1} & =\text { Kepemimpinan Pribadi } \\
\mathrm{X}_{2} & =\text { Perencanaan } \\
\mathrm{X}_{3} & =\text { Perbaikan Terus-menerus } \\
\varepsilon & =\text { error (kesalahan residu) }
\end{array}
$$

\section{HASIL PENELITIAN}

\section{Uji Validitas Dan Reliabilitas}

Uji validitas dan reliabilitas dilakukan berkenaan dengan ketepatan alat ukur terhadap konsep yang diukur sehingga benar-benar mengukur apa yang seharusnya diukur.

Tabel 1.

Hasil Uji Validitas dan Uji Reliabilitas Instrumen

\begin{tabular}{|c|c|c|c|c|c|}
\hline Variabel & $\begin{array}{c}\text { No. } \\
\text { Item }\end{array}$ & R Hitung & Keterangan & $\begin{array}{c}\text { Alpha } \\
\text { Chronbach }\end{array}$ & Keterangan \\
\hline & Item 1 & 0,418 & Valid & & \\
Kepemimpinan & Item 2 & 0,600 & Valid & & \\
Pribadi (X) $\left.\mathrm{X}_{1}\right)$ & Item 3 & 0,453 & Valid & 0,623 & \\
& Item 4 & 0,588 & Valid & & \\
& Item 5 & 0,487 & Valid & & \\
& Item 6 & 0,684 & Valid & & \\
& Item 1 & 0,645 & Valid & & \\
Perencanaan & Item 2 & 0,804 & Valid & & \\
$\left(\mathrm{X}_{2}\right)$ & Item 3 & 0,483 & Valid & \multirow{2}{*}{0,786} & \\
& Item 4 & 0,554 & Valid & & \\
& Item 5 & 0,718 & Valid & & \\
& Item 6 & 0,612 & Valid & & \\
& Item 7 & 0,634 & Valid & & \\
\hline
\end{tabular}




\begin{tabular}{|c|c|c|c|c|c|}
\hline & Item 8 & 0,611 & Valid & & \\
\hline & Item 1 & 0,585 & Valid & & \\
& Item 2 & 0,519 & Valid & & \\
Perbaikan Terus- & Item 3 & 0,427 & Valid & & \\
menerus & Item 4 & 0,443 & Valid & 0,712 & \\
$\left(X_{3}\right)$ & Item 5 & 0,460 & Valid & & \\
& Item 6 & 0,626 & Valid & & \\
& Item 7 & 0,692 & Valid & & \\
& Item 8 & 0,555 & Valid & & \\
& Item 1 & 0,677 & Valid & & \\
Kualitas Total Tim & Item 2 & 0,639 & Valid & & \\
(Y) & Item 3 & 0,626 & Valid & & \\
& Item 4 & 0,674 & Valid & \multirow{2}{*}{0,833} & \\
& Item 5 & 0,686 & Valid & & \\
& Item 6 & 0,668 & Valid & & \\
& Item 7 & 0,755 & Valid & & \\
& Item 8 & 0,629 & Valid & & \\
\end{tabular}

Sumber: Data diolah

Berdasarkan Tabel 1 diatas, ternyata hasil dari uji validitas dan reliabilitas pada penelitian yang dilakukan terhadap 46 responden menunjukkan bahwa seluruh ítem pernyataan valid dan reliabel. Item pernyataan dapat dikatakan valid apabila nilai rhitung > rtabel. Masing-masing item variabel dapat dikatakan reliabel apabila mempunyai nilai angka Alpha $\geq 0,6$.

\section{Uji Asumsi Klasik}

\section{Uji Normalitas}

Adanya normalitas dapat dideteksi dengan melihat penyebaran data (titik) pada sumbu diagonal dari grafik.

\section{Gambar 2}

\section{Hasil Uji Normalitas}

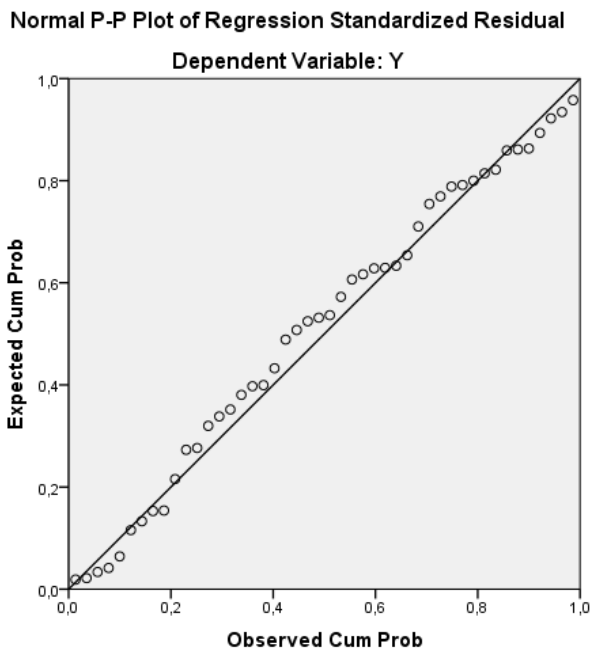


Pada gambar 2 terlihat bahwa titik-titik mendekati atau menyentuh garis diagonalnya yang berarti data telah berdistribusi normal sehingga proses pengujian data selanjutnya dapat dilakukan.

\section{Uji Multikolineritas}

Untuk mendeteksi keberadaan multikolinearitas dilakukan dengan melihat nilai Variance Inflation Factor (VIF) atau tolerance value. Nilai cutoff yang umum dipakai untuk menunjukkan adanya multikolineritas adalah apabila tolerance value kurang dari 0.10 atau nilai Variance Inflation Factor (VIF) lebih dari 10 (Ghozali, 2006:91-92). Hasil uji multikolineritas disajikan pada tabel 2 berikut:

Tabel 2

Hasil Uji Multikolineritas

\begin{tabular}{|c|l|c|c|}
\hline No & \multicolumn{1}{|c|}{ Variabel } & Tolerance & VIF \\
\hline 1. & Kepemimpinan Pribadi $\left(\mathrm{X}_{1}\right)$ & .675 & 1.481 \\
2. & Perencanaan $\left(\mathrm{X}_{2}\right)$ & .455 & 2.197 \\
3. & Perbaikan Terus-menerus $\left(\mathrm{X}_{3}\right)$ & .517 & 1.935 \\
\hline
\end{tabular}

Sumber: data diolah

Hasil perhitungan nilai Variance Inflation Factor (VIF) menunjukkan tidak ada satu variabel independen yang memiliki nilai tolerance value lebih dari 0.10 dan nilai VIF lebih dari 10. Jadi dapat disimpulkan bahwa tidak ada multikolineritas antar variabel independen dalam model regresi.

\section{Uji Heterokedastisitas}

Untuk mendeteksi ada tidaknya heterokedastisitas adalah dengan melihat ada tidaknya pola tertentu pada grafik scatterplot antara SREID dan ZPRED. 


\section{Gambar 3}

\section{Hasil Uji Heterokedastisitas}

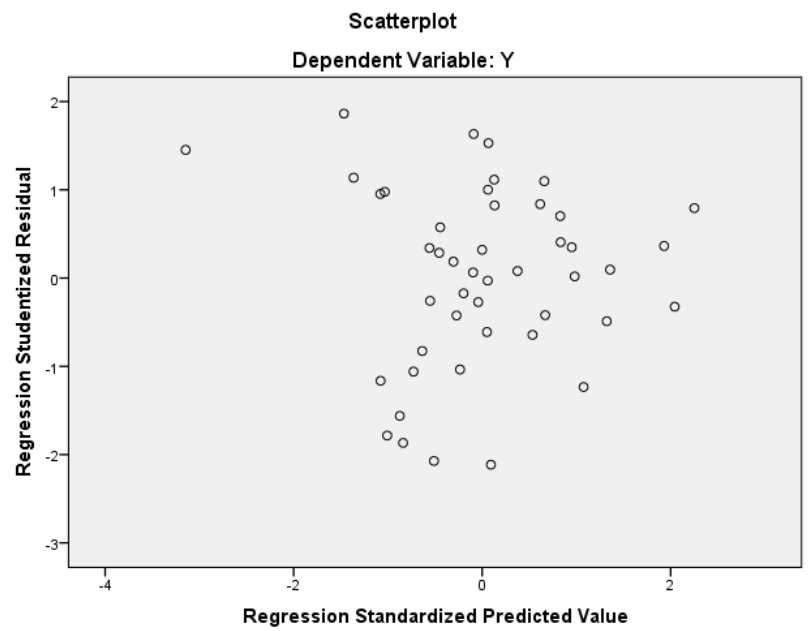

Dari gambar 3 terlihat bahwa titik-titik menyebar secara acak serta baik diatas maupun dibawah angka 0 pada sumbu $\mathrm{Y}$, sehingga dapat disimpulkan bahwa tidak terjadi heterokedastisitas pada model regresi yang digunakan.

\section{Uji Autokorelasi}

Uji yang digunakan untuk menguji adanya autokorelasi dalam suatu model regresi dapat dilakukan dengan melihat nilai durbin watson.

Tabel 3

Hasil Uji Autokorelasi

\begin{tabular}{|c|c|c|c|c|}
\hline & Du & DW & 4-du & Interprestasi \\
\hline Nilai & 1.666 & 2.027 & 2.334 & Tidak ada Autokorelasi \\
\hline
\end{tabular}

Sumber: data diolah

Pada tabel 3 diatas, diperoleh nilai durbin watson sebesar 2.027 lebih besar dari tingkat batas atas (du) 1.666 dan kurang dari 4 - 1.666 (4-du), maka dapat disimpulkan bahwa tidak terjadi autokorelasi pada model regresi yang akan digunakan. 


\section{Pengujian Hipotesis}

Tabel 4

Rangkuman Hasil Analisis Regresi

\begin{tabular}{lcc}
\hline \multicolumn{1}{c}{ Variabel Independen } & Koefisien Regresi & Prob sig \\
\hline Kepemimpinan Pribadi $\left(\mathrm{X}_{1}\right)$ & 0.004 & 0.986 \\
Perencanaan $\left(\mathrm{X}_{2}\right)$ & 0.074 & 0.685 \\
Perbaikan terus-menerus $\left(\mathrm{X}_{3}\right)$ & 0.490 & $0.018^{*}$ \\
$\mathrm{R}^{2}: 0.264$ & & \\
Konstanta : 11.068 & & \\
\hline
\end{tabular}

Sumber: data diolah

Dari tabel di atas, terlihat bahwa ketiga variabel independen yang dimasukkan dalam model ternyata tidak semuanya signifikan, hanya variabel Perbaikan terus-menerus $\left(\mathrm{X}_{3}\right)$ yang signifikan dengan nilai probabilitas masing-masing sebesar 0.018. Dengan melihat koefisien regresi, maka dapat dibuat persamaan (model) regresi sebagai berikut:

$$
\mathrm{Y}=11.068+0.004 \mathrm{X}_{1}+0.074 \mathrm{X}_{2}+0.490 \mathrm{X}_{3}
$$

Nilai konstanta sebesar 11.068 menunjukkan bahwa jika Tim Himadiksi tidak menerapkan kepemimpinan pribadi, perencanaan, dan perbaikan terus-menerus, maka kualitas total tim Himadiksi sebesar 11.068. Koefisien regresi 0.004 menunjukkan bahwa setiap peningkatan satu satuan kepemimpinan pribadi maka kualitas total tim Himadiksi akan meningkat sebesar 0.004 satuan. Koefisien regresi 0.074 menunjukkan bahwa setiap peningkatan satu satuan perencanaan maka kualitas total tim Himadiksi akan meningkat sebesar 0.074 satuan. Koefisien regresi 0.490 menunjukkan bahwa setiap peningkatan satu satuan perbaikan terus-menerus maka kualitas total tim Himadiksi akan meningkat sebesar 0.203 satuan.

\section{PEMBAHASAN}

\section{Pengaruh Kepemimpinan Pribadi Terhadap Kualitas Total Tim Himadiksi}

Pengaruh variabel kepemimpinan menunjukkan arah hubungan positif tetapi tidak signifikan terhadap kualitas total tim Himadiksi. Hasil tersebut terlihat dari besarnya nilai koefisien regresi sebesar 0.014 dengan tingkat signifikansi sebesar 0.868. Dengan demikian dapat disimpulkan bahwa Hipotesis 1 yang menyatakan bahwa kepemimpinan pribadi berpengaruh signifikan terhadap kualitas total tim Himadiksi, ditolak. Hasil penelitian ini memberikan bukti empiris bahwa kepemimpinan pribadi tidak mampu meningkatkan kualitas 
tim Himadiksi. Hal ini dikarenakan anggota tim Himadiksi masih belum sepenuhnya memaksimalkan potensi kepemimpinan pribadi yang dimiliki masing-masing individu, terutama motivasi diri. Menurut Gazpers dan Fontana (2011), seseorang yang memiliki motivasi diri lemah biasanya akan mengharapakan kekuatan dari luar (motivator eksternal) untuk menggerakkan mereka untuk mencapai tujuan. Motivasi diri merupakan kekuatan batin, dorongan hati, kehendak atau niat yang menyebabkan seseorang melakukan suatu tindakan dengan cara tertentu. Penetapan visi dan tujuan hidup yang jelas akan mampu menumbuhkembangan motivasi diri untuk mengarahkan seseorang menuju kesuksesan.

\section{Pengaruh Perencanaan Terhadap Kualitas Total Tim Himadiksi}

Pengaruh variabel perencanaan menunjukkan arah hubungan positif tetapi tidak signifikan terhadap kualitas total tim Himadiksi. Hasil tersebut terlihat dari besarnya nilai koefisien regresi sebesar 0.023 dengan tingkat signifikansi sebesar 0.792. Dengan demikian dapat disimpulkan bahwa Hipotesis 2 yang menyatakan bahwa perencanaan berpengaruh signifikan terhadap kualitas total tim Himadiksi, ditolak. Hasil penelitian ini memberikan bukti empiris bahwa perencanaan tidak mampu meningkatkan kualitas tim Himadiksi. Hal ini dikarenakan masing-masing anggota tim Himadiksi belum mampu menetapkan visi dan tujuan hidupnya dengan jelas, sehingga setiap individu sulit mengembangkan motivasi diri dan pada akhirnya berdampak pada penurunan kualitas tim Himadiksi. Gazpers dan Fontana (2011), berpendapat bahwa visi merupakan pandangan jauh kedepan, ke segala sesuatu yang diinginkan untuk terjadi. Visi yang jelas akan mengarahkan seseorang ke tujuan hidup yang terarah dan berhasil. Oleh sebab itu, orang yang sukses akan memandang setiap tugas dan penyelesaian tugas sebagai tiang-tiang kecil yang menyangga proyek kesuksesan besar yang telah ada dalam kerangka visi yang jelas tersebut.

\section{Pengaruh Perbaikan Terus-Menerus Terhadap Kualitas Total Tim Himadiksi}

Pengaruh perbaikan terus-menerus menunjukkan arah hubungan positif dan signifikan terhadap kualitas total tim Himadiksi. Hasil tersebut terlihat dari besarnya nilai koefisien regresi sebesar 0.490 dengan tingkat signifikansi sebesar 0.018. Dengan demikian dapat disimpulkan bahwa Hipotesis $\mathbf{3}$ yang menyatakan bahwa perbaikan terus-menerus berpengaruh signifikan terhadap kualitas total tim Himadiksi, diterima. Hasil penelitian ini memberikan bukti empiris bahwa perbaikan terus-menerus mampu meningkatkan kualitas tim Himadiksi. Hal ini menunjukkan bahwa setiap anggota tim Himadiksi selalu terbuka pada 
kritikan dan memandang setiap masalah yang timbul merupakan suatu kesempatan untuk melakukan perbaikan terus-menerus agar menjadi lebih baik dari kondisi sekarang, sehingga dapat membawa perubahan bagi diri sendiri dan Kualitas Total Tim Himadiksi. Hasil pengujian Hipotesis 3 di atas, memberikan bukti empiris yang mendukung hasil penelitian Tobing dan Fitriati (2009) yang berpendapat bahwa kesediaan untuk menerima kritik dan saran, keinginan untuk mengembangkan gagasan atau ide secara bersama serta terus melakukan perbaikan jika mengalami kegagalan dalam bekerja merupakan karakteristik yang membentuk organisasi belajar untuk meningkatkan kualitas sumber daya manusia dalam suatu organisasi. Aziz (2010) mengungkapkan bahwa learning organization sebagai prinsip untuk tetap belajar secara terus menerus berkelanjutan serta tidak takut dengan perubahan dan persaingan. Gazpers dan Fontana (2011) juga mengungkapkan bahwa faktor utama kemajuan perusahaan-perusahaan terbaik dunia dalam memenangkan persaingan global adalah motivasi yang kuat dari pihak manajemen untuk melakukan perbaikan kualitas terus-menerus. Dalam tim Himadiksi, yang berperan sebagai manajer adalah Ketua Program Studi beserta para Dosen di lingkup Program Studi Pendidikan Akuntansi yang senantiasa memberikan arahan serta dorongan pada setiap anggota tim himadiksi untuk terus maju dan memperbaiki kualitas diri.

\section{KESIMPULAN DAN SARAN}

Kualitas Total Individu yang terdiri dari kepemimpinan pribadi, perencanaan dan perbaikan terus-menerus secara simultan berpengaruh signifikan terhadap kualitas total tim Himadiksi. Namun secara parsial, variabel kepemimpinan pribadi dan perencanaan tidak berpengaruh terhadap kualitas total tim Himadiksi, hanya variabel perbaikan terus-menerus yang menunjukkan pengaruh positif dan signifikan terhadap kualitas total tim Himadiksi. Hal ini membuktikan bahwa Organisasi Himpunan Mahasiswa Pendidikan Akuntansi IKIP PGRI Madiun merupakan organisasi belajar, dimana setiap anggota tim selalu terbuka pada kritikan dan memandang setiap masalah yang timbul merupakan suatu kesempatan untuk melakukan perbaikan terus-menerus agar menjadi lebih baik dari kondisi sekarang, sehingga dapat membawa perubahan bagi diri sendiri dan Kualitas Total Tim Himadiksi.

Hasil penelitian ini diharapkan dapat dijadikan bahan pemikiran bagi pihak Manajemen Perguruan Tinggi di Indonesia untuk lebih memprioritaskan kualitas lulusan melalui upaya konsisten dalam membangun serta mengembangkan potensi diri mahasiswa. Salah satu upaya yang dapat dilakukan adalah dengan membangun kerjasama tim pada 
organisasi kemahasiswaan agar lulusan perguruan tinggi menjadi pribadi yang mandiri, kreatif, bertanggung jawab dan siap memasuki dunia kerja.

\section{DAFTAR PUSTAKA}

Aziz, Safrudin. 2010. Strategi Peningkatan Mutu Pada Perpustakaan Perguruan Tinggi. Artikel Perpustakaan dan Kepustakawanan UNIKA Soegiyapranata, Semarang.

Barizi, Ahmad dan Muhammad Idris. 2010. Menjadi Guru Unggul. Jogjakarta: Ar-Ruzz Media.

Chapagain, Dinesh P. 2013. Constructing an Objective Scale to Measure Character of Total Quality Person (TQP). http://www.dineshchapagain.com.np/quality_mindset.php, diunduh pada tanggal 9 Mei 2014.

Gaspersz, Vincent dan Avianti Fontana. 2011. Integrated Management Problem Solving. Vinchristo Publishing, Bogor.

Ghozali, Imam. 2006. Aplikasi Analisis Multivariate Dengan Program SPSS. Cetakan IV. Badan Penerbit Universitas Diponegoro Semarang.

Komariah, Aan dan Cepi Triatna. 2008. Visionary Leadership. Bumi Aksara, Bandung.

Milosan, Ioan. 2011. Studies About The Total Quality Management Concept. Acta Technica Corviniensis - Buletin of Engineering, Tome IV, Faculty of Engineering Hunedoara, Romania. ISSN 2067 - 3809.

Narimawati, Umi. 2014. Peranan Modal Intelektual Dosen Dalam Menciptakan Kualitas Lulusan. Majalah Ilmiah Unikom, Vol.6, No. 2.

Ningsih, Hadiah Fitriyah dan Lilis Cahayu.2013. Karakteristik Total Quality Management (TQM) Dalam Mempengaruhi Kinerja Manajerial Pada PT. X. Prosiding Call For Paper: Bidang Akuntansi, Fakultas Ekonomi Universitas Muhammadiyah, Sidoarjo.

Poernomo, Eddy. 2006. Pengaruh Kreativitas Dan Kerjasama Tim Terhadap Kinerja Manajer Pada PT. Jesslyn K Cakes Indonesia Cabang Surabaya. Jurnal Ilmu - Ilmu Ekonomi, Vol 6, No.2.

Sallis, Edward. 2011. Manajemen Mutu Terpadu Pendidikan. IRCiSoD, Yogyakarta.

Sule, Ernie Tisnawati dan Kurniawan Saefullah. 2010. Pengantar Manajemen. Kencana, Jakarta.

Tjiptono, Fandy dan Anastasia Diana. 2003. Total Quality Management. ANDI Penerbit, Yogyakarta. 
Tobing, Sondang Yohanna L. dan Rachma Fitriati. 2009. Pengaruh Organisasi Pembelajar Terhadap Kompetensi Pegawai Bank Bisnis dan Birokrasi. Jurnal Ilmu Administrasi Dan Organisasi, Volume 16 Nomor 1, ISSN 0854-3844.

Utomo, Hardi. 2010. Kontribusi Soft Skill Dalam Menumbuhkan Jiwa Kewirausahaan. Among Makarti, Vol.3 No.5.

Widhiarso, Wahyu. 2009. Evaluasi Soft Skills Dalam Pembelajaran. Makalah Disampaikan pada Kegiatan Seminar dan Sarasehan "Evaluasi Pembelajaran Mata Kuliah Umum Kependidikan” di FIP UNY tanggal 14 Februari 2009. 